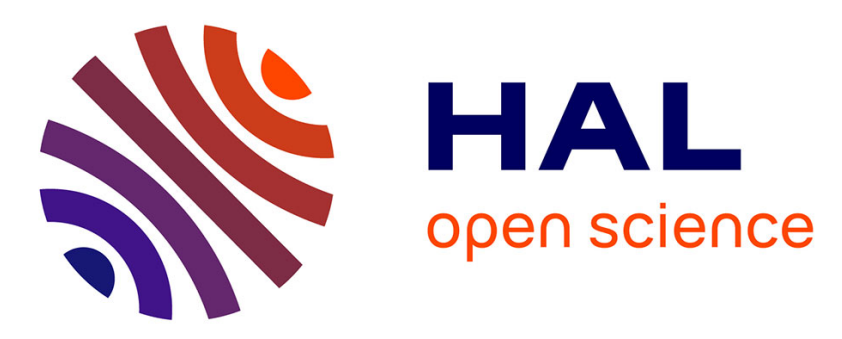

\title{
Genetic analysis of CHCHD10 in French familial amyotrophic lateral sclerosis patients
}

Elisa Teyssou, Laura Chartier, Mélanie Albert, Alexandra Bouscary, Jean-Christophe Antoine, Jean-Philippe Camdessanché, Francesco Rotolo, Philippe Couratier, François Salachas, Danielle Seilhean, et al.

\section{To cite this version:}

Elisa Teyssou, Laura Chartier, Mélanie Albert, Alexandra Bouscary, Jean-Christophe Antoine, et al.. Genetic analysis of CHCHD10 in French familial amyotrophic lateral sclerosis patients. Neurobiology of Aging, 2016, 10.1016/j.neurobiolaging.2016.03.022 . hal-01297339

\section{HAL Id: hal-01297339 \\ https: / hal.sorbonne-universite.fr/hal-01297339}

Submitted on 4 Apr 2016

HAL is a multi-disciplinary open access archive for the deposit and dissemination of scientific research documents, whether they are published or not. The documents may come from teaching and research institutions in France or abroad, or from public or private research centers.
L'archive ouverte pluridisciplinaire HAL, est destinée au dépôt et à la diffusion de documents scientifiques de niveau recherche, publiés ou non, émanant des établissements d'enseignement et de recherche français ou étrangers, des laboratoires publics ou privés. 


\section{Genetic analysis of CHCHD10 in French familial amyotrophic lateral sclerosis patients}

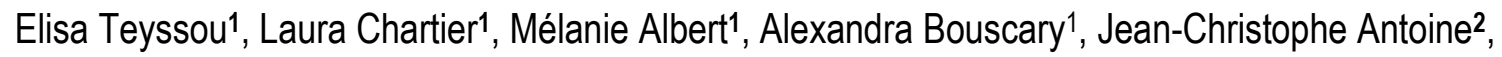
Jean-Philippe Camdessanché2, Francesco Rotolo², Philippe Couratier ${ }^{3}$, François Salachas ${ }^{4}$, Danielle Seilhean ${ }^{1,5}$, Stéphanie Millecamps ${ }^{1^{*}}$

1Institut du Cerveau et de la Moelle épinière (ICM), INSERM U1127, CNRS UMR 7225, Sorbonne Universités, Université Pierre et Marie Curie, Univ Paris 06, UPMC-P6 UMR S 1127, Hôpital de la PitiéSalpêtrière, Paris, France.

2Service de Neurologie, Centre Hospitalier Universitaire (CHU) de Saint-Etienne, Saint-Etienne, France. ${ }^{3}$ Service de Neurologie, CHU Dupuytren, Limoges, France.

4Département des Maladies du Système Nerveux, APHP, Centre de référence maladies rares SLA, Hôpital Pitié-Salpêtrière, Paris, France.

5Département de Neuropathologie, Assistance Publique Hôpitaux de Paris (AP-HP), Hôpital PitiéSalpêtrière, Paris, France.

"To whom correspondence should be addressed: Dr Stéphanie Millecamps, Institut du Cerveau et de la Moelle épinière, Groupe hospitalier Pitié-Salpêtrière, 83, Bd de l'Hôpital, 75013 Paris, France, tel : 33157274341 , e-mail: stephanie.millecamps@upmc.fr

Key words: Amyotrophic lateral sclerosis, familial ALS, Frontotemporal dementia, FTD, Frontotemporal lobar degeneration, FTLD, Genetic analysis, Motor neuron disease.

\section{Abstract.}

Mutations in $\mathrm{CHCHD10}$ have been reported as the cause of a large panel of neurological disorders. In order to confirm the contribution of this gene to amyotrophic lateral sclerosis (ALS) disease we analyzed the 4 coding exons of $\mathrm{CHCHD} 10$ by Sanger sequencing in a cohort of 118 French familial ALS already excluded for all known ALS related genes. We did not find any pathogenic mutation suggesting that CHCHD10 is not a major genetic cause of familial ALS, in France. 


\section{Introduction.}

CHCHD10 gene encodes a coiled-coil helix coiled-coil helix protein involved in the maintenance of mitochondrial organization, which is crucial for the function of neurons. Indeed, mutations in CHCHD10 have been identified in broad neurological diseases affecting peripheral or central nervous system neurons including axonal Charcot-Marie-Tooth Type 2 (Pasanen, et al., 2015), late-onset spinal motor neuronopathy (Penttila, et al., 2015), early-onset dementia (Dobson-Stone, et al., 2015), Parkinson's and Alzheimer's diseases (Zhang, et al., 2015).

A CHCHD10 mutation (c.176C>T, p.Ser59Leu, S59L) was recently identified by whole-exome sequencing analysis in a French family with a mitochondrial DNA instability disorder (Bannwarth, et al., 2014). The eight affected patients carrying this mutation presented a large panel of clinical phenotypes including cerebellar ataxia, motor neuron disease, myopathy, bulbar syndrome, sensorineural deafness and cognitive decline resembling dementia (Bannwarth, et al., 2014). The S59L mutation was further identified in 1 out of 21 families with pathologically proven frontotemporal dementia/amyotrophic lateral sclerosis (FTD/ALS) (Bannwarth, et al., 2014). FTD is characterized by a degeneration of frontal and temporal lobe neurons leading to personality and behavior changes and/or language impairment. ALS is characterized by degeneration of central and peripheral motor neurons leading to a rapidly fatal paralysis. FTD is diagnosed in 13-14\% of ALS patients (Montuschi, et al., 2015; Phukan, et al., 2012) and $12-14 \%$ of patients with FTD secondarily develop ALS (Burrell, et al., 2011; Lomen-Hoerth, et al., 2002).

Several studies have documented the identification of $\mathrm{CHCHD} 10$ mutations in FTD/ALS (Chaussenot, et al., 2014; Dobson-Stone, et al., 2015; Dols-Icardo, et al., 2015), FTD (Dols-Icardo, et al., 2015; Zhang, et al., 2015), or pure ALS patients (Abdelkarim, et al., 2015; Chio, et al., 2015; Dols-Icardo, et al., 2015; Johnson, et al., 2014; Kurzwelly, et al., 2015; Muller, et al., 2014; Ronchi, et al., 2015; Zhang, et al., 2015). In contrast, other studies did not find any pathogenic variant in ALS patients despite frequent mutations being identified in pure FTD patients from the same geographic area (Jiao, et al., 2015; 


\section{ACCEPTED MANUSCRIPT}

Marroquin, et al., 2015; Wong, et al., 2015). In France CHCHD10 is responsible for $2.6 \%$ of FTD/ALS cases (Chaussenot, et al., 2014). We aimed to determine the $\mathrm{CHCHD10}$ mutation frequency in a large cohort of French familial ALS (FALS) patients.

\section{Methods.}

A cohort of 118 FALS was analyzed in this study. FTD was secondarily diagnosed in $15 \%$ of these ALS patients. Patients were previously analyzed for main ALS related genes (supplementary material). The 4 CHCHD10 coding exons (ENST00000484558) were analyzed by Sanger sequencing. Sequence of the primers and PCR conditions are available upon request.

\section{Results.}

We identified four variants in $\mathrm{CHCHD10}$ in our population of ALS patients: three synonymous at the heterozygous state (c.141G>A, p.Gln47Gln, Q47Q; c.234G>A, p.Ser78Ser, S78S; c.330G>A, p.Leu110Leu, L110L) and one missense at the homozygous state (c.286C>A, p.Pro96Thr, P96T). This substitution is predicted to activate a cryptic acceptor site which could impact on $\mathrm{CHCHD10}$ splicing (Netgene2, http://www.cbs.dtu.dk/services/NetGene2/). In silico analyses predicted that the P96T amino acid change was possibly damaging (PolyPhen-2, http://genetics.bwh.harvard.edu/pph2/) or deleterious (SIFT, http://sift.bii.a-star.edu.sg/) for the protein functions. Three of the variants we identified (S78S, P96T and L110L) were already reported in public databases (Supplementary Table 1). The L110L variant, which is more frequent in African than in European population (Supplementary Table 1), was identified in a patient from Martinique origin (Supplementary Table 2). The patient carrying the P96T variant at the homozygous state had a slow ALS disease duration of 108 months (Supplementary Table 2).

\section{Discussion.}

The analysis of 118 French ALS patients identified three synonymous variants that are not likely to be pathogenic. We also identified the missense P96T variant at the homozygous state in a patient presenting a slow progression of the disease (9 years). Similar slow disease duration (6 to 17 years) 
was previously observed for patients carrying R15L, G66V or P80L CHCHD10 variants (Muller, et al., 2014; Zhang, et al., 2015). This P96T variant was predicted to impact CHCHD10 splicing and to have a deleterious effect on protein function, supporting the view that it could be pathogenic. Interestingly, it was already identified at the homozygous state in 2 Spanish ALS patients (Dols-Icardo, et al., 2015). However this variant was also previously identified in Italian ALS patients and controls (Chio, et al., 2015) and is more frequent in some specific populations: frequencies are 0.02533 (EXAC) and 0.005 (1000 Genomes project) for Latino and Iberian Spanish controls, respectively. Thus, as for the P34S variant, which was identified at a similar frequency in patients and controls, (Abdelkarim, et al., 2015; Dols-Icardo, et al., 2015; Marroquin, et al., 2015; Wong, et al., 2015), the pathogenicity of the P96T variant should be interpreted with caution and is likely not sufficient to cause ALS. Overall, as none of our variants seemed to be pathogenic, we concluded that $\mathrm{CHCHD10}$ is not a primary cause of FALS in France.

\section{Disclosure statement.}

The authors declare no actual or potential conflicts of interest.

\section{Acknowledgements.}

We acknowledge the patients and their family. We thank the Généthon cell and DNA bank (Evry, France) and the ICM DNA and cell bank (Paris, France) for patients DNA. This study was funded by the Association française contre les myopathies (AFM, France, contract R11038DD), the Association pour la Recherche sur la Sclérose latérale amyotrophique et autres maladies du motoneurone (ARSla, France, contract R13132DD), the Aide à la Recherche des Maladies du Cerveau association (ARMC, France, contract R14169DD) and a collaborative research program established between ICM, CHU de Limoges and Université de Limoges (ICM.SCI.1800.CRCO). E.T. is supported by a PhD Fellowship from AFM (\#18145).

\section{References}

Abdelkarim, S.,Morgan, S.,Plagnol, V.,Lu, C.H.,Adamson, G.,Howard, R.,Malaspina, A.,Orrell, R.,Sharma, N.,Sidle, K.,Clarke, J.,Fox, N.C.,Rossor, M.N.,Warren, J.D.,Clark, C.N.,Rohrer, J.D.,Fisher, E.M.,Mead, 
S.,Pittman, A., Fratta, P. 2015. CHCHD10 Pro34Ser is not a highly penetrant pathogenic variant for amyotrophic lateral sclerosis and frontotemporal dementia. Brain, doi: 10.1093/brain/awv223.

Bannwarth, S.,Ait-El-Mkadem, S.,Chaussenot, A.,Genin, E.C.,Lacas-Gervais, S.,Fragaki, K.,Berg-Alonso, L.,Kageyama, Y.,Serre, V.,Moore, D.G.,Verschueren, A.,Rouzier, C.,Le Ber, I.,Auge, G.,Cochaud, C.,Lespinasse, F.,N'Guyen, K.,de Septenville, A.,Brice, A.,Yu-Wai-Man, P.,Sesaki, H.,Pouget, J., Paquis-Flucklinger, V. 2014. A mitochondrial origin for frontotemporal dementia and amyotrophic lateral sclerosis through CHCHD10 involvement. Brain 137(Pt 8), 2329-45.

Burrell, J.R.,Kiernan, M.C.,Vucic, S., Hodges, J.R. 2011. Motor neuron dysfunction in frontotemporal dementia. Brain 134(Pt 9), 2582-94.

Chaussenot, A.,Le Ber, I.,Ait-El-Mkadem, S.,Camuzat, A.,de Septenville, A.,Bannwarth, S.,Genin, E.C.,Serre, V.,Auge, G.,Brice, A.,Pouget, J., Paquis-Flucklinger, V. 2014. Screening of CHCHD10 in a French cohort confirms the involvement of this gene in frontotemporal dementia with amyotrophic lateral sclerosis patients. Neurobiol Aging 35(12), 2884 e1-4.

Chio, A.,Mora, G.,Sabatelli, M.,Caponnetto, C.,Traynor, B.J.,Johnson, J.O.,Nalls, M.A.,Calvo, A.,Moglia, C.,Borghero, G.,Monsurro, M.R.,La Bella, V.,Volanti, P.,Simone, I.,Salvi, F.,Logullo, F.O.,Nilo, R.,Battistini, S.,Mandrioli, J., Tanel, R.,Murru, M.R.,Mandich, P.,Zollino, M.,Conforti, F.L.,Brunetti, M.,Barberis, M.,Restagno, G.,Penco, S., Lunetta, C. 2015. CHCH10 mutations in an Italian cohort of familial and sporadic amyotrophic lateral sclerosis patients. Neurobiol Aging 36(4), 1767 e3-6.

Dobson-Stone, C.,Shaw, A.D.,Hallupp, M.,Bartley, L.,McCann, H.,Brooks, W.S.,Loy, C.T.,Schofield, P.R.,Mather, K.A.,Kochan, N.A.,Sachdev, P.S.,Halliday, G.M.,Piguet, O.,Hodges, J.R., Kwok, J.B. 2015. Is CHCHD10 Pro34Ser pathogenic for frontotemporal dementia and amyotrophic lateral sclerosis? Brain 138(Pt 10), e385.

Dols-Icardo, O.,Nebot, I.,Gorostidi, A.,Ortega-Cubero, S.,Hernandez, I.,Rojas-Garcia, R.,Garcia-Redondo, A.,Povedano, M.,Llado, A.,Alvarez, V.,Sanchez-Juan, P.,Pardo, J.,Jerico, I.,Vazquez-Costa, J.,Sevilla, T.,Cardona, F.,Indakoechea, B.,Moreno, F.,Fernandez-Torron, R.,Munoz-Llahuna, L.,Moreno-Grau, S.,Rosende-Roca, M.,Vela, A.,Munoz-Blanco, J.L.,Combarros, O.,Coto, E.,Alcolea, D.,Fortea, J.,Lleo, A.,Sanchez-Valle, R.,Esteban-Perez, J.,Ruiz, A.,Pastor, P.,Lopez De Munain, A.,Perez-Tur, J., Clarimon, J. 2015. Analysis of the CHCHD10 gene in patients with frontotemporal dementia and amyotrophic lateral sclerosis from Spain. Brain 138(Pt 12), e400.

Jiao, B.,Xiao, T.,Hou, L.,Gu, X.,Zhou, Y.,Zhou, L.,Tang, B.,Xu, J., Shen, L. 2015. High prevalence of CHCHD10 mutation in patients with frontotemporal dementia from China. Brain.

Johnson, J.O.,Glynn, S.M.,Gibbs, J.R.,Nalls, M.A.,Sabatelli, M.,Restagno, G.,Drory, V.E.,Chio, A.,Rogaeva, E., Traynor, B.J. 2014. Mutations in the CHCHD10 gene are a common cause of familial amyotrophic lateral sclerosis. Brain 137(Pt 12), e311.

Kurzwelly, D.,Kruger, S.,Biskup, S., Heneka, M.T. 2015. A distinct clinical phenotype in a German kindred with motor neuron disease carrying a CHCHD10 mutation. Brain 138(Pt 9), e376.

Lomen-Hoerth, C.,Anderson, T., Miller, B. 2002. The overlap of amyotrophic lateral sclerosis and frontotemporal dementia. Neurology 59(7), 1077-9.

Marroquin, N.,Stranz, S.,Muller, K.,Wieland, T.,Ruf, W.P.,Brockmann, S.J.,Danzer, K.M.,Borck, G.,Hubers, A.,Weydt, P.,Meitinger, T.,Strom, T.M.,Rosenbohm, A.,Ludolph, A.C., Weishaupt, J.H. 2015. Screening for CHCHD10 mutations in a large cohort of sporadic ALS patients: no evidence for pathogenicity of the p.P34S variant. Brain, doi: 10.1093/brain/awv218.

Montuschi, A.,Iazzolino, B.,Calvo, A.,Moglia, C.,Lopiano, L.,Restagno, G.,Brunetti, M.,Ossola, I.,Lo Presti, A.,Cammarosano, S.,Canosa, A., Chio, A. 2015. Cognitive correlates in amyotrophic lateral sclerosis: a population-based study in Italy. J Neurol Neurosurg Psychiatry 86(2), 168-73.

Muller, K.,Andersen, P.M.,Hubers, A.,Marroquin, N.,Volk, A.E.,Danzer, K.M.,Meitinger, T.,Ludolph, A.C.,Strom, T.M., Weishaupt, J.H. 2014. Two novel mutations in conserved codons indicate that CHCHD10 is a gene associated with motor neuron disease. Brain 137(Pt 12), e309.

Pasanen, P.,Myllykangas, L.,Poyhonen, M.,Kiuru-Enari, S.,Tienari, P.J.,Laaksovirta, H.,Toppila, J.,Ylikallio, E., Tyynismaa, H., Auranen, M. 2015. Intrafamilial clinical variability in individuals carrying the CHCHD10 mutation Gly66Val. Acta Neurol Scand, doi: 10.1111/ane.12470. 
Penttila, S.,Jokela, M.,Bouquin, H.,Saukkonen, A.M.,Toivanen, J., Udd, B. 2015. Late onset spinal motor neuronopathy is caused by mutation in CHCHD10. Ann Neurol 77(1), 163-72.

Phukan, J.,Elamin, M.,Bede, P.,Jordan, N.,Gallagher, L.,Byrne, S.,Lynch, C.,Pender, N., Hardiman, O. 2012. The syndrome of cognitive impairment in amyotrophic lateral sclerosis: a population-based study. J Neurol Neurosurg Psychiatry 83(1), 102-8.

Ronchi, D.,Riboldi, G.,Del Bo, R., Ticozzi, N.,Scarlato, M.,Galimberti, D.,Corti, S.,Silani, V.,Bresolin, N., Comi, G.P. 2015. CHCHD10 mutations in Italian patients with sporadic amyotrophic lateral sclerosis. Brain 138(Pt 8), e372.

Wong, C.H.,Topp, S.,Gkazi, A.S.,Troakes, C.,Miller, J.W.,de Majo, M.,Kirby, J.,Shaw, P.J.,Morrison, K.E.,de Belleroche, J.,Vance, C.A.,Al-Chalabi, A.,Al-Sarraj, S.,Shaw, C.E., Smith, B.N. 2015. The CHCHD10 P34S variant is not associated with ALS in a UK cohort of familial and sporadic patients. Neurobiol Aging 36(10), 2908 e17-8.

Zhang, M.,Xi, Z.,Zinman, L.,Bruni, A.C.,Maletta, R.G.,Curcio, S.A.,Rainero, I.,Rubino, E.,Pinessi, L.,Nacmias, B.,Sorbi, S., Galimberti, D.,Lang, A.E.,Fox, S.,Surace, E.I.,Ghani, M.,Guo, J.,Sato, C.,Moreno, D.,Liang, Y.,Keith, J., Traynor, B.J.,St George-Hyslop, P., Rogaeva, E. 2015. Mutation analysis of CHCHD10 in different neurodegenerative diseases. Brain 138(Pt 9), e380.

\section{Supplementary material.}

\section{Methods.}

The diagnosis of ALS was based on the El Escorial criteria established by the World Federation of Neurology (Brooks, et al., 2000) and that of FTLD was based on international diagnosis criteria (Rascovsky, et al., 2011). Criterion for family inclusion was that at least two members were affected by ALS. FALS patients were devoid of mutation in C9ORF72, SOD1, TARDBP, FUS, VAPB, ANG, UBQLN2, VCP or PFN1 (Millecamps, et al., 2012a; Millecamps, et al., 2012b; Millecamps, et al., 2010b). These FALS patients had also systematically been screened for DAO, OPTN, SQSTM1, SS18L1 and MATR3 (Millecamps, et al., 2011; Millecamps, et al., 2010a; Millecamps, et al., 2014; Teyssou, et al., 2013; Teyssou, et al., 2014) mutations. However patients carrying the variants we previously reported in these later genes were included in this study as the pathogenicity of these variants still remains unclear. Mean age of onset of the analyzed series was 60 years (SEM 1, range 33 to 80 years) and mean disease duration was 48 months (SEM 6, range 6 to 260 months). ALS patients were evaluated with standardized behavioral procedures for cognitive impairments whenever this was possible, considering the rapid progression of the disease in these patients. 


\begin{tabular}{|c|c|c|c|c|}
\hline Variant & rs number & ExAC & ESP & 1000 Genomes \\
\hline c.286C>A, p.Pro96Thr & rs111677724 & $\begin{array}{l}\text { Eur: } 0.000998 \\
\text { Afr: } 0.2559\end{array}$ & $\begin{array}{l}\text { EA: } 0 \\
A A: 0.015\end{array}$ & $\begin{array}{l}\text { Eur: } 0 \\
\text { Afr: } 0.057\end{array}$ \\
\hline c.330G>A, p.Leu110Leu & rs138183274 & $\begin{array}{l}\text { Eur: } 0 \\
\text { Afr: } 0.0085\end{array}$ & $\begin{array}{l}\text { EA: } 0 \\
\text { AA: } 0.0073\end{array}$ & $\begin{array}{l}\text { Eur: } 0 \\
\text { Afr: } 0.012\end{array}$ \\
\hline c.234G>A, p.Ser78Ser & rs111527940 & $\begin{array}{l}\text { Eur: } 0.01314 \\
\text { Afr: } 0.003376\end{array}$ & $\begin{array}{l}\text { EA: } 0.0101 \\
\text { AA: } 0,0025\end{array}$ & $\begin{array}{l}\text { Eur: } 0.010 \\
\text { Afr: } 0\end{array}$ \\
\hline c.141G>A, p.GIn47GIn & I & 1 & l & I \\
\hline
\end{tabular}

Supplementary Table 1. Frequency of heterozygous $\mathrm{CHCHD10}$ variants in control populations.

ExAC: Exome Aggregation Consortium (http://exac.broadinstitute.org), ESP: the NHLBI Exome Sequencing Project (http://evs.gs.washington.edu/EVS), 1000 Genomes project (http://www.1000genomes.org/), Eur: European (non-Finnish), Afr: African, EA: European American, AA: African American.

\begin{tabular}{|c|c|c|c|c|c|c|}
\hline Variant & Sexe & Origin & $\begin{array}{l}\text { Age of } \\
\text { onset }\end{array}$ & Site of onset & $\begin{array}{l}\text { Disease } \\
\text { duration }\end{array}$ & Remark \\
\hline P96T & $F$ & French & $53 y$ & $\begin{array}{l}\text { upper limb } \\
\text { (distal) }\end{array}$ & 108 months & $\begin{array}{l}\text { Predominant lower } \\
\text { motor neuron } \\
\text { involvement }\end{array}$ \\
\hline L110L & $F$ & Martinique & $43 y$ & $\begin{array}{l}\text { lower limb } \\
\text { (distal) }\end{array}$ & na & \\
\hline S78S & M & French & $68 \mathrm{y}$ & $\begin{array}{l}\text { upper limb } \\
\text { (distal) }\end{array}$ & 19 months & ALS-FTD \\
\hline Q47Q & $F$ & French & $59 y$ & $\begin{array}{l}\text { lower limb } \\
\text { (distal) }\end{array}$ & 15 months & \\
\hline
\end{tabular}

Supplementary Table 2. Clinical data of ALS patients carrying a CHCHD10 gene variant.

F: Female / M: Male / y: years / na: not available. 


\section{Supplementary references}

Brooks, B.R.,Miller, R.G.,Swash, M., Munsat, T.L. 2000. El Escorial revisited: revised criteria for the diagnosis of amyotrophic lateral sclerosis. Amyotroph Lateral Scler Other Motor Neuron Disord 1(5), 293-9.

Millecamps, S.,Boillee, S.,Chabrol, E.,Camu, W.,Cazeneuve, C.,Salachas, F.,Pradat, P.F.,Danel-Brunaud, V.,Vandenberghe, N.,Corcia, P.,Le Forestier, N.,Lacomblez, L.,Bruneteau, G.,Seilhean, D.,Brice, A.,Feingold, J.,Meininger, V., LeGuern, E. 2011. Screening of OPTN in French familial amyotrophic lateral sclerosis. Neurobiol Aging 32(3), 557 e11-3.

Millecamps, S.,Boillee, S.,Le Ber, I.,Seilhean, D.,Teyssou, E.,Giraudeau, M.,Moigneu, C.,Vandenberghe, N.,Danel-Brunaud, V.,Corcia, P.,Pradat, P.F.,Le Forestier, N.,Lacomblez, L.,Bruneteau, G.,Camu, W.,Brice, A.,Cazeneuve, C.,Leguern, E.,Meininger, V., Salachas, F. 2012a. Phenotype difference between ALS patients with expanded repeats in C9ORF72 and patients with mutations in other ALSrelated genes. J Med Genet 49(4), 258-63.

Millecamps, S.,Corcia, P.,Cazeneuve, C.,Boillee, S.,Seilhean, D.,Danel-Brunaud, V.,Vandenberghe, N.,Pradat, P.F.,Le Forestier, N.,Lacomblez, L.,Bruneteau, G.,Camu, W.,Brice, A.,Meininger, V.,LeGuern, E., Salachas, F. 2012b. Mutations in UBQLN2 are rare in French amyotrophic lateral sclerosis. Neurobiol Aging 33(4), 839 e1-3.

Millecamps, S.,Da Barroca, S.,Cazeneuve, C.,Salachas, F.,Pradat, P.F.,Danel-Brunaud, V.,Vandenberghe, N.,Lacomblez, L.,Le Forestier, N.,Bruneteau, G.,Camu, W.,Brice, A.,Meininger, V., LeGuern, E. 2010a. Questioning on the role of $D$ amino acid oxidase in familial amyotrophic lateral sclerosis. Proc Natl Acad Sci U S A 107(26), E107; author reply E8.

Millecamps, S.,De Septenville, A.,Teyssou, E.,Daniau, M.,Camuzat, A.,Albert, M.,LeGuern, E.,Galimberti, D.,Brice, A.,Marie, Y., Le Ber, I. 2014. Genetic analysis of matrin 3 gene in French amyotrophic lateral sclerosis patients and frontotemporal lobar degeneration with amyotrophic lateral sclerosis patients. Neurobiol Aging 35(12), 2882 e13-5.

Millecamps, S.,Salachas, F.,Cazeneuve, C.,Gordon, P.,Bricka, B.,Camuzat, A., Guillot-Noel, L.,Russaouen, O.,Bruneteau, G.,Pradat, P.F.,Le Forestier, N., Vandenberghe, N.,Danel-Brunaud, V.,Guy, N., ThauvinRobinet, C.,Lacomblez, L.,Couratier, P.,Hannequin, D.,Seilhean, D.,Le Ber, I.,Corcia, P.,Camu, W.,Brice, A.,Rouleau, G.,LeGuern, E., Meininger, V. 2010b. SOD1, ANG, VAPB, TARDBP, and FUS mutations in familial amyotrophic lateral sclerosis: genotype-phenotype correlations. J Med Genet 47(8), $554-60$.

Rascovsky, K.,Hodges, J.R.,Knopman, D.,Mendez, M.F.,Kramer, J.H.,Neuhaus, J.,van Swieten, J.C.,Seelaar, H.,Dopper, E.G.,Onyike, C.U.,Hillis, A.E.,Josephs, K.A.,Boeve, B.F.,Kertesz, A.,Seeley, W.W., Rankin, K.P.,Johnson, J.K.,Gorno-Tempini, M.L.,Rosen, H.,Prioleau-Latham, C.E.,Lee, A.,Kipps, C.M.,Lillo, P.,Piguet, O.,Rohrer, J.D.,Rossor, M.N.,Warren, J.D.,Fox, N.C.,Galasko, D.,Salmon, D.P.,Black, S.E.,Mesulam, M.,Weintraub, S.,Dickerson, B.C.,Diehl-Schmid, J.,Pasquier, F.,Deramecourt, V.,Lebert, F.,Pijnenburg, Y.,Chow, T.W.,Manes, F.,Grafman, J.,Cappa, S.F.,Freedman, M.,Grossman, M., Miller, B.L. 2011. Sensitivity of revised diagnostic criteria for the behavioural variant of frontotemporal dementia. Brain 134(Pt 9), 2456-77.

Teyssou, E., Takeda, T.,Lebon, V.,Boillee, S.,Doukoure, B.,Bataillon, G.,Sazdovitch, V.,Cazeneuve, C.,Meininger, V.,LeGuern, E.,Salachas, F.,Seilhean, D., Millecamps, S. 2013. Mutations in SQSTM1 encoding p62 in amyotrophic lateral sclerosis: genetics and neuropathology. Acta Neuropathol 125(4), 511-22.

Teyssou, E.,Vandenberghe, N.,Moigneu, C.,Boillee, S.,Couratier, P.,Meininger, V.,Pradat, P.F.,Salachas, F.,Leguern, E., Millecamps, S. 2014. Genetic analysis of SS18L1 in French amyotrophic lateral sclerosis. Neurobiol Aging 35(5), 1213 e9- e12. 